\title{
THE SOUND OF EVIL: A PERSPECTIVE OF COMPARATIVE LITERATURE
}

\author{
Lusia Kristiasih Dwi Purnomosasi \\ PBI/FPBS/IKIP PGRI MADIUN \\ (lusiakdp@gmail.com)
}

\begin{abstract}
The representation of evil in The Scarlet Letter, Madam Bovary, Anna Karenina, and Lady Chatterley's Lover is a choice to be compared by the theory of comparative literature of Claudio Guillen.It is called thematology. It is based on the assumption that a theme will be different as it is accepted by different cultures. Internationality is applied among others. The evil functions as a representation of a sinner in The Scarlet Letter in line with external marital affairs by the main character. It is due to the belief of witch that leads to the special woman. The witch as the representation of evil changes to the beggar in Madam Bovary and a railway station officer in Anna Karenina. Both reflect the different social stratification as the effect of materialism. Lady Chatterley's Lover has transformed to an invisible representation of evil. It is the mentality of capitalism. The transformation of those evil in the novels is created from the stereotype towards the cursed by society. It deals with the belief and status.
\end{abstract}

Key words: comparative literature, internationality, thematology.

\section{A. INTRODUCTION}

Guillen proposes the meaning of theme as "what the writer modifies, modulates, overturns, not what he says but what he uses to say with ..." (1993:197). It means the theme is the object which is a tool to deliver the author's idea in the story. Considering the statement, it is necessary to see the evil as the object of discussion by which the author of the novel uses it to say something. The existence of the evil is as the choice since the novels would be compared are much more wellknown as its adultery and controversial sexuality. Those are The Scarlet Letter (Nathaniel Hawthorne), Madam Bovary (GustaveFlaubert), Anna Karenina (Leo Tolstoy,) and Lady Chatterley's Lover (D.W. Lawrence). It would be challenging to see how the evil works upon those novels and what the author is intended to say with. 
The evil is as a tool used by the author to say something in the story. It can be said that the evil is the primary theme in which the performances are different time to time. The main characters make contact face to face with the evil by accident that corresponds with society condemn. The judgments of being wrong in adultery by the main character's circumstances seem to be the reason of the evil appearance. The evils are also condemned. However, the performances of evil are different from one to the others. A witch in The Scarlet Letter, a blind beggar in Madam Bovary, and a dirty railway station officer in Anna Karenina are minor characters, but none in the Lady Chatterley's Lover. None does not mean not existed. The later shows invisible. In short, in spite of the similarities, differences are existed in those four novels due to the capability of the author whether the object (the theme, the evil) is modified, transformed, adopted, or reborn. That is why it is triggered the researcher to get the reason why the same function of evil in the novels come into being in diversity. How such diversities are connected is about to get dialog among them.

The dialog constructs the structure of theme metamorphosis diachronically. Thus, this study will deliver the problems of how the internationality in the novels by using the evil as the theme. Therefore, the researcher assumes that the same issue will be different when it is perceived in different cultures.

\section{Method}

Comparative literature is the paradigm of the study. It is intended to making comparison among novels by which the data are taken from. The phenomenon of the evil will be investigated deeply through text. It is to find the quality of it (Kothari, 2004:3) by answering questions of how and why (Hancock, 1998:2). Therefore, this is a qualitative study by using comparative approach. The method of collecting data suitable with is documentation by which data are in the form of text in the novels as well as references and other sources dealing with social, historical, and cultural data. It will be analyzed by the narrative technique since it deals with the literary works (Wahyuni, 2012:121) and interpretation upon it. 


\section{B. DISCUSSION}

\section{Evil: Woman: Condemn: A Dialog in between Novels}

The researcher intends to say that the mysterious figure is the nature of evil that will be elaborated. The author seems to have no reason to meet both the evil and the main characters in the novels. In fact, their meeting is significant. The researcher startsthe analysis from a witch names Mistress Hibbins who glares Hester Prynne in an occasion in The Scarlett Letter. The appearance of Mistress Hibbins is believed to be a sign that Hester Prynne brings demon. In the novel, it is like the shadow who Hester Prynne really is by getting eye contact which says much more than words. The silent connection is suffice to make society recognize that Hester Prynne is a witch as well just because she refuses to confess her secret father of her little child. It pays much attention because they live in Boston, Massachusetts.

Relating to a witch and Hester Prynne, the researcher provides historical data. A witch is a sensitive issue in $17 \mathrm{C}$ in Massachusetts. The following is data connected to early Puritan inhabitant in America where witchcraft is cursed and hunted. Luedtke in Marty explains that it begins with Puritanism which believes that they are special people chosen by God to build a nation as the model of Christianity. They make themselves a colony by communalism system where diversity is not allowed strongly. It aims to build a perfect society (1994: 189-201). In other case, Wheller and Becker (1986: 1-19) note the woman names Anne Hutchinson who is sentenced alienated to the remote of Narraganset island since the court finds no guilty. Her denial is an evidence that it has happened already a rebellion toward the rules of Puritanism. Eventually, people believe that she is guilty as she gives birth a paralyzed baby in that island. Her baby is condemned as a monster come from a sinner mother. What the case of Anne says shows that the strict Puritan rules are going to be broken continuously by new generation in growing cities and society (Wheeler and Becker, 1986: 19). Breaking rule done by one person means punishment for all colonists. Sin has been there. Wheller and Becker state further that it brings consequences that the punishment of Israel in the old times of Moses will be coming soon at Massachusetts. People experience hysteria where their anxiety gets to its peak in 1680. They have 
been locked themselves at churches for days and nights to reach salvation by listening to sermons on Day of Doom or God's Quarrel with New England. The pressure of being fear and anxious transforms people into panic. Church claims possessed to those who are struck by panic. It is believed that the punishment of God is about to begin. 19 people are assassinated, 1 person committed to be hanged, and much more are imprisoned. Most of them are women. Since then, women who seems suspected a sinner are easily judged to be a witch. Hundreds of women are killed by this incident. A witch is those who are possessed by demon in her body. The researcher, then, could say that demon is a word to call an analog of women who dare to say the truth out of the Bible. Demon is the enemy of God which should be banished and hated.

What is meant by demon in the novel (The Scarlet Letter) is the belief of society upon which the interpretation of being Christian must be fulfilled. The unfaithful ones are those who say and behave differently as they listen to their conscience not the Bible. Those are the demon or possessed by demon. Hester Prynne says nothing but defense to keep her own rights to be silent. Being silent is forbidden. It is a sin to avoid the judges, the representative of God in the world.

Considering the Bible, the woman as the representation of Eve who is condemned to bring man (Adam) on earth is the source of society to also condemn unfaithful woman as a witch. These data prove the reaction of Boston, Massachusetts people, to the existence of Hester Prynne as a sinner to be similar with a witch. The meeting between Mistress Hibbins and Hester Prynne is signed to be the condemnation in society.

It seems the evil in the witch as the effect of the belief transform to other forms. The evil comes into being in Madam Bovary as the shadow of demon.It is seen by Emma Bovary three times by accident. She ignores. Yet, she is impressed so much. It is a beggar. The story shows that the impression originally comes from the disgusting appearance of him but eventually it is by a song sung by him. Furthermore the beggar's dirty and disgusting nature is indeed bothered Emma's mentality. Even his song is heard as she is dying. The death of Emma is the important moment that this incident is shadowed by the beggar's song. The researcher argues that the 
appearance of the beggar is significant even though he is less appeared. The first impression in the first meeting with the beggar make Emma fear of something. Considering the role of Emma in the story the researcher confirms that Emma is afraid of being poor. This feeling drives Emma to be a character who loves to seek something new in her life. Her passion is about getting rich with the whole luxurious facilities as the riches have. That is why, the beggar is the same as the poor living she denies.

The poor is a nightmare. The following is the data to strengthen that interpretation. To do with it is necessary to present the historical background as data quoted from Fisher (1957: 696-706). It begins with Voltaire who brings new perspectives of nation from England. Letters sur les Anglais is a work of him containing his idea of freedom that any citizen should get free to express idea and opinion, experience no violence and injustice, and get freedom in religion. England is a suggested model to France where welfare, security, and liberty are guaranteed by nation.

Voltaire inspires Montesquieu to live in England for two years, 1729-1731, Fisher says further. Montesquieu writes a book entitles Esprit des Lois (1748) in where he reveals his findings that a big secret of being freedom in England is the separation affairs among institution of judicative, executive, and legislative. Those two new perspectives brought by Voltaire and Montesquieu who have read a lot and they influence people to force the movement of liberty to change France to be an ideal freedom nation. The researcher sees that France insists on the mentality movement. This spirit of mentality movement, the author describes in the novel, is the representation of how Emma get bored to her circumstances. By the data, the researcher comes to the conclusion that the passionate Emma is the passion of change of better France as the description in Emma's phantasm.

The existence of a beggar corresponds with the phantasies belong to Emma. The author tells that she experiences reality that she belongs to a secondary bourgeois social status (Barbier in Sartono Kartodirdjo, 1983: 76) but she lives in imaginary world. The researcher has considered the data by Fisher and interprets that the 
sparkling big cities, upper class life style, and sensation of being rich is the will of France to make England as its ideal model of nation. In other words, wealthy is still far from France to reach. The researcher sees that less achievement in progress by France is the failed phantasm of Emma in the novel. It deals with the reality, in contrast with phantasy, that Emma hates being poor so much. Living poor is living in poverty as the beggar. The big threat for Emma is poverty and its consequences. Therefore, she prefers committed suicide by swallowing arsenic than living with no money. The researcher interprets that the beggar is the representation of poverty. Poverty is a nightmare. The author shows that Emma finally as poor as the beggar. The researcher sees the beggar is exactly the shadow of the life to go belong to Emma.

The researcher finds the similar phenomenon in Anna Karenina where Anna experiences to be an eye witness of the accident in the railway station. The author tells that the crash cut into pieces the body of the officer. Blood and death in the railway station seems to be the foreshadowing of Anna's end of life. Beginning from this point, in some extent, nothing corresponds with myth as evil in The Scarlet Letter and threat of poverty as evil in Madam Bovary but death. That is why the researcher thinks it is better to start investigation on death. The following data are taken from the research done by Lusia K.D.P in her thesis (2013: 118-120) that the dominant conflict in Anna Karenina is the contradiction between social values and personal selffulfillment. The social values of aristocracy insists on women to be the second sex under the men as the primary sex. Therefore, in the novel, Anna feels sick with morality. It is supported by Turner (1995:261-268) in his article who says that both the characters and the readers get dialog that implied morality. Greene (1997:106125 ) in his article also talk about morality in the form of stereotype of woman as a mother, a wife, and a woman.The researcher finds that Anna is the victim of social convention. However, she keeps to dare taking risks by challenging her society. As the data prove, the researcher sees Anna's death is her choice from the beginning of her life with Karenin and the first contact with Vronsky due to morality bond. The burden lies on social morality. The matter of morality is clearly the cause of the 
death. The meeting of Anna and the railway station officer happens at the death of the officer seems to be the death of Anna in the same way at the same place.

The evil in the Lady Chatterley's Lover is different from those three previous novels. It is an inanimate or invisible but it relates to the conflicts between Connie and her husband, Clifford Chatterley. The evil appears along the story and it becomes dominant. The author shows that their frequently meetings does not make their relation closed psychologically. Connie is engaged to the strange connection of her husband's misconception world view. This is the nature of the evil in the novel dealing with fate. To show it, the researcher begins the analysis from the Bible which talks about charity by rich people. The author writes,

... The point is not: take all thou hast and give to the poor, but use all thou hast to encourage the industry and give work to the poor. ...

(Lawrence, 1958: 199)

It is important to quote that sentences for it has two discussions; charity and social class. The explanation will be in the following paragraphs.

First, it deals with charity which is suggested to Christian to do as God's order. It is said to share wealth for rich people to help the poor. It is intended to the interpretation of charity in the old times, butit does not say so to the new one. The researcher finds data to show this statement. John Winthrop shares his idea in his speech of A Model of Christian Charity before his followers about Law of Gospel (Boller Jr and Story, 1984: 12). At the opening of his speech, Winthrop delivers statement that the form of charity changes times to times for Christian as the recent situation suggested. Once, Christians are ordered to sell all the belongings and give it to the poor. In other occasion, Christians are ordered to give more than money but the ability of thinking, too, to the poor. It differs by times.

The researcher confirms the changes of the interpretation of the Bible goes along with the changes of the world as stated by Jones (trans by Ahmad Fedyani Saifuddin, 2010: 93). It means that the situation in the world influences the way of people thought constructing metamorphosis of new interpretation on charity. It is proven that the interpretation of charity by Winthrop happens to Clifford in the novel. In the era of industrialism where the setting of the story is set Clifford believes that 
the charity changes from money and ability to giving industrial jobs. The riches provide industries to the poor. Industries provides jobs. Jobs results money to cover life for the poor. This is the transformation of charity meaning by Clifford.

Second, it is about social classes. The quotation suggests two different classes; the rich and the poor as destiny from Heaven. God creates different classes from the beginning that it should not be ignored by human in the world. The researcher finds that nothing is wrong with differences in the society and remains the same. The author shows the statement of Clifford dealing with unarguable belief of distinction in the universe,

'That is fate. Why is the star Jupiter bigger than the star Neptune? You can't start altering the make-up of things!'(Lawrence, 1958: 199)

Clifford persists the argument that God creates distinction in the universe such as planets. This belief puts human in position of incapable to change fate. The researcher concludes Clifford's belief of fate is the belief of different classes in society. Different social class brings different places, course of life, and ability that make unity of both classes is impossible to do. The researcher supports it by providing the social data which show a Victorian hymn taken from Jones (2010:93)

The rich lives in the estates

The poor stays at its gates

God creates them high and low

And decides their destiny

The data show that the institution of religion declares into the institution of society. It aims to give long life last to the social practices. Further, Jones confirms in his discussion of Marxist's perspective that the characteristic of production and religion are in harmony unless the feudalism will not last (2010:93). Relating to what Jones states and what the author's description of Clifford, it is confirmed that both rules and laws let the riches to provide industries, mining, factories, and cities to earn life for the poor. Helping earning life is a recent form of charity. The researcher concludes that there is nothing wrong in Clifford's conception of fate. In the contrary, all are wrong based on the conceptions of Connie. This contradiction seems to be the enemy one to the other. It creates conflicts between Clifford and Connie as a spouse. The 
presence of Clifford is the presence of the evil invisibly for Connie. The humanity of Clifford is corrupted by the way of Clifford's thinking about world and life. Connie can touch Clifford everyday physically but she cannot reach him spiritually.

The analysis shows that evil exists in different form but it leaves an interesting curiosity to be discussed that the evil contacts the women as the main characters of the novels. It seems no coincidence to reconcile them together in the stories of The Scarlet Letter, Madame Bovary, Anna Karenina, and Lady Chatterley's Lover. The discussion will be related to condemn since the common assumption lives in society that adultery done by women is a shame.

The researcher sees that the adultery in the novels is done by reason but the facts also show that the society where the main characters live condemn extra marital relation. It proves the contradicted values between social convention on womanhood and the existence of women as independent individual. Women has still no power to share the bargaining position. The social mentality toward women can be traced from the belief construction in the Bible. The researcher provides social data concerning on original sin. Christians believe on the original sin brought before human was born on earth. The Divine ancestor of the sinner is believed done by Adam and Eve in Heaven. It is demon provocation to Eve to break the law of being closed to the forbidden fruit. The existence of demon is in the form of a snake which finally succeed to provoke Eve. This is declared as the weakness of female. Since then, women is believed to be the place where the power of demon stays as in Niken Supriatin's research which finds that it is a woman who suffered from possession of spirits(2014). The researcher finds that women who easily receive provocations should be blamed to the disorder in the world such as committing adultery which create condemn. Eve's disobedience is fate for women to be guarded by rule to conduct life well. Therefore, it must be morality directly stated to the women much more than men. This researcher's argument goes along with the social data provided and the facts in the novels.

The evil performance is condemned by society in The Scarlet Letter. However, the evil performance in Madam Bovary is condemned byEmma herself. 
There is no relation with condemn in society relating to the evil in Anna Karenina. Meanwhile, Lady Chatterley's Lover reveals the invisible evil. The evil appears shadowing adultery as the bad conduct by women. Adultery is condemned by society in all novels due to dealing with female stereotype. It is the goal of Guillen that novels would be connected in international and inter-temporal like an invisible web by thematology.

\section{The Metamorphosis of the Evil}

The previous dialog leads to the structural construction of thematology. The researcher prefers starting from The Scarlett Letter to Lady Chatterley's Lover diachronically in consideration on times (the later is the younger period in 20C) as suggested by Guillen.

The existence of evil in the form of a witch in The Scarlet Letter indicates a living misconception to the belief of Puritan in early American colonist. The similar position of a witch and Hester Prynne seems to be argued by the author. The scarlet "A" stand for Adultery in Hester Prynne's chest transformed into Able (Lawrence, 1959: 156). The author wants to say what Puritan's interpretation on Bible should not be suitable with the nature of humanity. Besides, the voice of God is the voice of the leaders as the practices in the governing nation is a misconception. In short, a witch is as the past nostalgic belief stand face to face with the free will of humanity.

It would be the same idea in Madam Bovary but it turns to the individual battle within Emma. It leads to the psychological phenomenon that the evil in the form of a beggar is the threat constructed by Emma's world view. Its existence does not stand alone as in The Scarlet Letter but side by side with two entities; the alchemist and the merchant as stated in the following paragraphs. Guillen says it polysemy. The following is a concise companion with those two.

Homais, the alchemist prefers to worship science than God. He blames that everything existed in the world and any problem available could be explained and solved by science. He claims that his God is scientist such as James Watt and Voltaire. The social data show that the rationalism of science is the influence 
rationalism and science from England. It is due to England has been running on the industrial revolution since renaissance period. Meanwhile, Voltaire has been visited England and brings new awareness (Fisher, 1957: 696-706). The alchemy contributes to the death of Emma.

Lheureux, the salesman, and Guillaumin, the broker indicate new trend in business. It is supported by the data that France has just become the growing country signed by the growing cities (such as Rouen, Lyon, Bordeoux, Marseille, and Paris) and new bourgeoise dynasty (such as the Rouxs and the Bonaffes) (Barbier in Sartono Kartodirdjo, 1983: 76 and 87). The story tells that its existence contributes to make Emma hopeless and trap her into the debt and poverty. The story shows the passion's phantasm of the riches' life dominantly triggers Emma in debt. The researcher interprets realizing she will be nothing to have, it reminds her to the beggar's life. She is more frightening with the life in poverty than her dept. That is why, living in poverty has triggered Emma to end her life.

The evil in the form of the railway station officer who comes to death in Anna Karenina is presented with the poor peasant. It seems to be a separated division. It means there is no connection directly between the death officer and the poor peasant, and so does the story(Nia Setyaningrum,2014). It is supported by the story that the appearance of the peasant exists in her dream once. The researcher also finds the reason in Nia Setyaningrum (2014) that the riches people is divided into two; the aristocrats and the rich peasant. Another data shown in the novel says that the peasant includes into the conservative class who becomes the principle handicap of progression of revolutionary movement to make changes in Soviet (Tolstoy, 2007: 10). However, the peasant has no relation with Anna since the author talks much about norm and morality as indicated previously.

These polysemy of theme are absence in Lady Chatterley's Lover even there is a change of the existence of the evil. Three novels show that the evil is casted as characters but this novel provides the evil in the invisible one. It means there is no character role as the evil. Those three previous novels provides less meeting than the one in Lady Chatterley's Lover. Reviewing from the plot, The Scarlet Letter and 
Lady Chatterley's Lover end in happy ending where the evil has been conquered by the resistance of the main characters. It means the spirit of being survived is reborn after its absence due to the death of the main characters in both Madam Bovary and Anna Karenina Meyer (1995: 245-259) supports the researcher to say that the ending life of Emma is assumed to be read by Tolstoy in Anna Karenina.

\section{CONCLUSSION}

Comparison in literary works opens the dialog among them to see that there are differences as well as similarities which are unique. All the characters in the novels being discussed experience free will and its cost. Adultery is the manifestation of woman free will against the border stereotyping customs. Though those novels are more famous of sexuality than it, the comparative literature of Guillen proves that the object of evil is able to speak about society.

It is the work of new definition of theme and historical investigation proposed by Guillen. The object of evil shows the theme modified from The Scarlet Letter to Madam Bovary and Anna Karenina as the presence of the bourgeoisie and science and peasant. It also opens that the object of evil transformed to be invisible thing in the form of misconception thought though the bourgeoisie and science still existed but omitting peasant. The appearance of the evil contribute to the destiny of the main characters.

\section{REFERENCES}

Boller Jr, Paul F dan Story, Roland. 1984. A More Perfect Union. Documents in U.S. History. Boston: Houghton Mifflin Company.

Flaubert, Gustave. 1990. Madame Bovary. Winarsih Arifin (trans). Jakarta: Pustaka Jaya.

Greene, Gayle. 1977. "Woman, Character, and Society in Toltoy's Anna Karenina" in Frontiers: A Journal of Woman Studies Vol. 2 No. 1 pp. 106-125. Retrieved on 22/10/2013 19:50 
Guillen, Claudio. 1993. The Challenge of Comparative Literature. Transl by Cola Franzen. Cambridge: Harvard University Press.

Hancock, Beverley. 1998. An Introduction to Qualitative Research. Nottingham: Trent Focus.

Hawthorne, Nathaniel. 1959. The Scarlet Letter. New York: A Signet Classics.

Kothari, C.R. 2004. Research Methodology: Method and Techniques. New Delhi: New Age International (P) Ltd.

Lawrence, D.H. 1959. Lady Chatterley's Lover. London: William Heinemann Ltd. Luedtke, Luther S. (Ed). 1994. Mengenal Masyarakat dan Budaya Amerika Serikat. Trans by Hermoyo dan Masri Maris. Jakarta: Yayasan Obor Indonesia.

Meyer, Priscilla. 1995. “Anna Karenina: Tolstoy’s Polemic with Madame Bovary” in Russian Review Vol. 54, No. 2, pp. 243-259 retrieved on 22/10/2013 19:45

Salam, Aprinus; Chambert-Loir, Henri; Salleh, M. Haji (eds). 2011. Jejak Sastra dan Budaya. Yogyakarta: Elmatera.

Setyaningrum, Nia. 2014. Anna and Russian Society Idea in Tolstoy's Anna Karenina. (Undergraduate) Thesis. IKIP PGRI Madiun. Unpublished.

Supriatin, Niken. 2014. Woman and Possession: A Study of Popular Literature. (Undergraduate) Thesis. IKIP PGRI Madiun. Unpublished.

Tolstoy, Leo. 1963. Anna Karenina. New York: A Signet Classic.

Turner, C.J.G. 1995. "Psychology, Rhetoric, and Morality: In the Bottom of Whose Heart?” in The Slavic European Journal. Vol. 39, No. 2, Pp 261-268. Retrieved on $22 / 10 / 201319: 51$.

Wahyuni, Sari. 2012. Qualitative Research and Method: Theory and Practice. Jakarta: Salemba Empat.

Wheeler, William Bruce dan Becker, Susan D. 1986. Discovering the American Past: A Look at the Evidence. Vol 1. Boston: Houghton Mifflin Company. 